\title{
KÜSIMUSTE SÕNAJÄRJE MÕJU NÄHTUD ISIKU MÄLETAMISE TÄPSUSELE 4- JA 6-AASTASTEL EESTI LASTEL
}

\author{
Kristjan Kask, Reili Argus, \\ Kristel Veerus, Kreet Kokla
}

Ülevaade. Kohtusüsteemis on oluline lapskannatanut või -tunnistajat üle kuulata kvaliteetselt, et lapse meenutatava info hulk oleks suur ja võimalikult täpne. Uurimuse eesmärgiks on leida lastele esitatavate küsimuste sõnastuse, eelkõige sõnajärje mõju vastuste kvaliteedile ja kvantiteedile. Katses osales 100 nelja- ja kuueaastast last, kes nägid neile võõrast inimest ning vastasid järgmisel päeval küsimustele nähtud isiku kohta. Lastele esitatud küsimustes kasutati erinevat sõnajärge verb oli kas lause keskel või lause lõpus. Ühe grupi lastelt küsiti läbivalt ainult ühe või teise sõnajärjega küsimusi; teise grupi laste käest mõlema sõnajärjega küsimusi läbisegi. Tulemustest selgus, et sõnajärje varieerimisel (verb küsimuse keskel võrrelduna verbiga küsimuse lõpus) ei olnud statistiliselt olulist mõju ei infoühikute hulgale ega täpsusele. Ilmnesid vanuselised erinevused: kuueaastased lapsed olid küsimustele vastates täpsemad kui nelja-aastased lapsed. Kui võrreldi läbivalt ainult üht tüüpi sõnajärje kasutamist (kas verb ainult küsimuse keskel või ainult lõpus) või erineva sõnajärjega küsimuste vaheldamist küsitlemise käigus (mõnes küsimuses oli verb keskel, mõnes lõpus), vastasid lapsed nii pikemalt kui ka täpsemalt juhtudel, kus kasutati ainult ühe sõnajärjega küsimusi. Uuringu tulemuste põhjal võiks soovitada, et kui lastelt küsimusi küsida ning oluline on saada täpset infot, siis ei tasuks erineva sõnajärjega küsimusi vaheldada, vaid küsida küsimusi ainult üht sõnajärge kasutades (kõikides küsimustes verb alati küsimuse keskel või alati küsimuse lõpus).*

Võtmesõnad: laste küsitlemine, küsimuste sõnajärg, lastekeel 


\section{Sissejuhatus}

Alates 1980. aastatest on laste tunnistuste osakaal kohtuprotsessides olnud tõusuteel (Poole, Dickinson 2013). Seetõttu on oluline lapskannatanut või -tunnistajat üle kuulata kvaliteetselt, et lapse meenutatava info hulk oleks suur ja see info oleks võimalikult täpne. Lapsi pole peetud väga usaldusväärseteks tunnistajateks, aga uuringud näitavad, et lapsed on võrreldes täiskasvanutega võimelised andma sama täpseid kirjeldusi (Kask, Bull 2009). Seega peab professionaalne küsitleja olema teadlik mälu erinevatest protsessidest, lapse kognitiivsest arengust ja efektiivseimatest küsitlusviisidest.

Juba eelkooliealised lapsed suudavad vaba meenutuse käigus meelde tuletada isiku ja sündmuse (Sporer 1996); samuti teiste inimeste käitumise kohta käivaid detaile (Ceci, Crossman jt 1998). Autobiograafilise mälu arengus on oluline osa ka sotsiaalsel komponendil, nagu näiteks lapsega toimunud meenutusvestlusel peale sündmuse toimumist (Tõugu jt 2011). Dekle jt (1996) on välja toonud, et võrreldes täiskasvanutega on laste vaba meenutus lühem, aga mitte ilmtingimata ebatäpsem. Samas on just viimaste aastakümnete uurimused püüdnud aidata lastel rohkem meelde tuletada nähtud isiku kohta käivaid detaile, kuna spontaanselt kirjeldavad lapsed inimese välimust vähe (Poole, White 1991).

Lastel on eriti raske hinnata nähtud isiku pikkust, vanust ja kaalu või kehaehitust. Uuringud on näidanud, et isegi 12 aasta vanused lapsed võivad olla sellistes hinnangutes ebatäpsed, eriti just võõrast inimest nähes (Davies jt 1988). Põhjuseks võib olla see, et lapsed ise on võrreldes täiskasvanutega lühikesed ning seetõttu tunduvad kõik täiskasvanud neile pikana; sama kehtib ka vanuse kohta. Hadyn Ellis (1980) on ka välja toonud, et võrreldes täiskasvanutega ei ole lastel spetsiifilisi teadmisi näiteks ka näo vananemise kohta.

Isikukirjeldustes on leitud, et väiksemad lapsed (eriti eelkooliealised) võivad rohkem mainida nähtud isiku käitumist või tegevust, seevastu teismelised aga rohkem nähtud isiku välimust (King, Yuille 1986). Riietust mäletatakse tavaliselt hästi, aga sarnaselt juustega on need ühed kergemini muudetavad tunnused.

Seetõttu on püütud kasutada erinevaid abivahendeid (anatoomiliselt korrektne nukk, kehakaart, joonistus, etalon), suurendamaks laste isikukirjeldustes info hulka ja täpsust (vt Meissner jt 2006). Paraku pole need meetodid suurt läbimurret toonud, kuna info hulk võib küll suureneda, aga samas suureneb ka ebatäpsete detailide arv, nt anatoomiliste nukkude (Ceci, Bruck 1995) või etaloni kasutamise korral, kus lapsel paluti meenutada nähtud isikut ja võrrelda oma mälupilti küsitlejaga (vt Kask jt 2007).

Kõige täpsemad on alaealiste tunnistajate esmased ütlused ning see, kui kasutatakse lapse arengutaset arvestavaid küsitlemismeetodeid (Lamb jt 2000), nagu näiteks NICHD (National Institute of Child Health and Human Development) protokoll (vt Lamb jt 2008, samuti Kask 2007, Rammo 2006). NICHD protokollis on järgmised põhimõtted: last julgustatakse rääkima toetava õhkkonna loomise kaudu; küsitleja kohaldab intervjuud lapse arengu eripäradega (vähendatakse keelelist keerukust ja välditakse lapse katkestamist); last valmistatakse küsitlemiseks ette kui informatsiooni edastajat (reeglid küsitlemise ajal käitumiseks, last treenitakse meenutama sündmusele spetsiifilisi detaile) ja suurendatakse küsitleja toetumist küsimuse eri liikidele. NICHD protokolli kasutades tõusis uurijatel 4-13-aastaste seksuaalselt 
ärakasutatud laste küsitlemisel avatud küsimuste proportsioon ülekuulamisel tavapäraselt 10-20\%-lt 50\%-le (Orbach jt 2000). Võrreldes mittestruktureeritud intervjuu kasutamisega meenutati rohkem infot vastuseks avatud küsimustele ja vähem infot sugestiivsetele ja suletud küsimustele (Sternberg jt 2001, Kask 2012).

Oluline on last küsimustega mitte suunata ning lasta tal nähtud sündmust vabalt meenutada. Uuringud on välja toonud, et kõige parema tulemuse annabki vaba meenutus (laps räägib oma sõnadega) ja avatud küsimused (mis, kus, kes, millal) (Kask, Bull 2009, Hutcheson jt 1995). Küsides lapstunnistajatelt avatud küsimusi, annavad lapsed sama täpseid tunnistusi kui täiskasvanud (Poole, White 1991). Samas, küsides lapselt suletud (nt kas-küsimused) või suunavaid küsimusi (küsimus millegi kohta, mida laps pole veel maininud), kasvab ebatäpsete detailide hulk lapse vastustes (Kask, Bull 2009, Kask 2012).

\subsection{Eriküsilause sõnajärjest eesti keeles}

Avatud küsimusi vormistatakse eesti keeles eriküsilausega. Eriküsilauses paikneb lause alguses küsituum, mis annab küsimusele kommunikatiivmodaalse tähenduse ja küsimuse mõjuala (vt EKG 1993: 613). Eesti keelele on üldiselt omane (st et ka statistiliselt kõige sagedasem) nn V2-sõnajärg ehk verb paikneb lauses teisel positsioonil kas subjekti või mõne muu lauseliikme järel (EKK: 431, Tael 1988: 40). Selline nn põhisõnajärg on iseloomulik neutraalsele, lihtsa struktuuriga kontekstivabale normaallausele (vt Lindström, ilmumas). Suulises kõnes on aga siiski Liina Lindströmi sõnul V2-printsiibil väiksem mõju kui kirjakeeles, olulisemad on muud tegurid (Lindström 2002: 102, 2005: 173).

Eesti lause sõnajärjele avaldab põhiliselt mõju infostruktuur, st teema-reema ehk tuntud või uue info paigutus lauses, ning fookus. Fokuseerimine on lause mingi osa esiletõstmine kas rõhu ja intonatsiooni või sõnajärje abil ja nii ongi üks rõhutamise viis esiletõstetava elemendi nihutamine kas lause algusesse või lõppu (EKG 1993: 195).

Küsilauses paikneb fookus lause alguses küsituumas (Lindström 2005: 174) ehk siis küsisõnas. Ühtlasi on küsilause uus info ehk reemaosa ehk see info, mida teada soovitakse, samuti küsisõna. Samas ei ole fookus mitte alati seotud uue-tuntud eristusega, st et ka tuntud elemendid võivad olla fokuseeritud (Lindström 2005: 28).

Lindströmi järgi (2005: 44) kaldub eesti keeles olema verb lause lõpus küsisõnaga algavates eriküsilausetes (nt Kes külla tuleb?). Sellises eriküsilauses on uus info ehk reema ja ühtlasi ka fookus küsisõna kes. Kui aga nihutada verb tema neutraalselt lauselõpupositsioonilt ettepoole ning viimaseks elemendiks jääb mõni teine lauseliige, nt adverbiaal, asetub hoopis see oma ebahariliku lauselõpulise asendi tõttu fookusesse: Kes tuleb külla?

\subsection{Uuringu eesmärk}

Eestis ei ole vaadeldud seda, kuidas küsimuse keeleline pool ehk näiteks sõnajärg või väljendite/sõnade valik lapse vastust mõjutab. Ainuke teadaolev infokild küsimuse sõnajärje mõju kohta pärineb Liina Paju bakalaureusetööst, kust selgus, et 
kui lastega tehtud keelekatses kohendati küsimuste sõnajärg loomulikumaks (st paigutati verb küsimuse lõppu, nt Kes loeb mida? vs. Kes mida loeb? ), siis suurenes õigete vastuste hulk umbes 5\% (Paju 2014). Kuigi Paju töös ei kontrollitud, kas sõnajärje muutmise mõju oli statistiliselt oluline, andis see siiski siinsele uuringule lähteimpulsi ja põhjuse oletada, et laste vastuste täpsus võib sõltuda küsimuste sõnajärjest.

Siinse uurimuse eesmärk on leida lastele esitatavate küsimuste sõnastuse, eelkõige sõnajärje mõju vastuste kvaliteedile ja kvantiteedile. Kuna laste antud isikukirjeldused on lühikesed ja nende kvaliteet sõltub küsimusest, siis võib see oleneda ka n-ö järgmisest tasandist ehk küsimuse täpsemast sõnastusest ja sõnajärjest. Seega on oluline uurida, kas sõnajärje muutmine küsimuses aitab lastel rohkem meenutada, ilma et info täpsus selle all kannataks.

Katse 15 küsimusest olid 14 eriküsilaused. Katses varieeriti 12 küsimuse sõnajärge nii, et osa küsimusi oli eriküsilausetele tüüpilise sõnajärjega, st et verb paiknes küsimuse lõpus, nt Mis tal seljas oli??, ning osa küsimuste sõnajärge muudeti nii, et verb nihutati lauselõpupositsioonilt ettepoole, nt Mis tal oli seljas? Kuna eriküsilause loomulikum sõnajärg on just selline, kus verb asub küsilause lõpus (Lindström 2005: 44), võis seetõttu eeldada, et sellistele küsimustele annavad lapsed täpsemaid või teistsuguseid vastuseid kui neile, kus küsilause sõnajärg on markeeritud ehk kus lause lõpus paikneb mingi muu element, mitte verb.

Sellest lähtuvalt püstitati järgmised uurimisküsimused:

1. Kas lapsele esitatud küsimuse sõnajärg avaldab mõju vastuste kvantiteedile ja kvaliteedile?

2. Kas ja millised erinevused ilmnevad nelja- ja kuueaastaste laste vastuste kvantiteedis ja kvaliteedis?

\section{Meetod}

\subsection{Katseisikud}

Katses osalejad valiti mugavusvalimi põhimõttel. Valimi täitmiseks võeti ühendust lasteaedadega, neile tutvustati läbiviidavat uurimust ning paluti katse korraldamiseks luba. Katse viidi läbi viies lasteaias: ühes Hiiumaa ning neljas Tallinna lasteaias. Katses osales 100 nelja- $(n=39)$ ja kuueaastast $(n=61)$ last, kellest 44 olid poisid ja 56 tüdrukud. Laste vanematelt küsiti katse läbiviimiseks kirjalikku nõusolekut.

\subsection{Protseduur}

Katse viidi läbi kahel järjestikusel päeval. Esimesel päeval käis lasteaia rühmas külaline, kes veetis lastega aega 5-10 minutit. Katses kasutati kaheksat eri stiimulisikut. Kõik stiimulid olid naisterahvad vanuses 20-25. Stiimulisik ütles lastele enda nime ja vanuse ning seejärel toimus lühike tegevus. Enamasti loeti ette kasvataja antud raamatust lühike muinasjutt või luuletus. Järgmisel päeval küsitles sama rühma lapsi üks kahest küsitlejast, kasutades ettevalmistatud küsimustikku. Kõigepealt lasti lapsel vabalt meenutada nähtud isikut (Eile käis teil keegi rühmas. Mis sul selle 
kohta meeles on?). Seejärel küsiti lapselt küsimusi, mis puudutasid peamiselt isiku välimust, aga ka nime, tegevust ja vanust. Iga last küsitleti individuaalselt vaikses ruumis. Ühe lapse küsitlemiseks kulus keskmiselt 3-5 minutit.

Üks küsitleja küsis küsimusi, kasutades läbivalt ainult üht või teist sõnajärge ( $n=41$, vt tabel 1); teine küsitleja küsis lapse käest küsimusi viisil, kus olenevalt lapsest olid juhuslikustatult mõned küsimused ühe sõnajärjega (verb lause keskel) ja mõned küsimused teise sõnajärjega (verb lause lõpus, $n=59$ ). Esimesel juhul kirjutati laste vastused paberile; teisel juhul laste vastused audiosalvestati. Kolme küsimuse sõnajärge ei muudetud ( $\mathrm{nr} 1$ isiku sugu, $\mathrm{nr} 14$ isiku tegevus ning nr 15 muu).

Kogutud andmed transkribeeriti, sisestati andmetöötlusprogrammi MS Excel ning analüüsiti andmetöötlusprogrammiga SPSS 19. Kodeeriti igale küsimusele antud vastuses sisalduvate infoühikute arv, vastuse täpsus ning see, kas vastuses oli kirjeldatud õiget kategooriat. Üheks infoühikuks on loetud üht lapse esitatud kirjeldavat fakti, näiteks juuksevärvi küsimuse vastus pruunid juuksed sisaldab üht infoühikut, pruunid, lokkis juuksed kaht infoühikut. Lapse vastus loeti valeks, kui laps jättis küsimusele vastamata või vastas vale infoga. Vastuste täpsus kodeeriti järgmiselt: $\mathrm{O}=$ vale / puuduv vastus, $1=$ õige vastus.

Tabel 1. Lastelt küsitud küsimused

\begin{tabular}{|c|c|c|c|}
\hline $\begin{array}{l}\text { Küsimuse } \\
\text { number }\end{array}$ & $\begin{array}{c}\text { Ilma sõnajärge } \\
\text { muutmata }\end{array}$ & Sõnajärg 1 & Sõnajärg 2 \\
\hline 1 & Kas ta oli mees või naine? & & \\
\hline 2 & & Mis ta nimi oli? & Mis oli ta nimi? \\
\hline 3 & & Milline ta välja nägi? & Milline nägi ta välja? \\
\hline 4 & & Milline ta kehakuju oli? & Milline oli ta kehakuju? \\
\hline 5 & & Milline ta nägu oli? & Milline oli ta nägu? \\
\hline 6 & & Millised ta juuksed olid? & Millised olid ta juuksed? \\
\hline 7 & & Mis ta juuksevärv oli? & Mis oli ta juuksevärv? \\
\hline 8 & & Mis tal seljas oli? & Mis tal oli seljas? \\
\hline 9 & & $\begin{array}{l}\text { Mis värvi kampsun/pluus } \\
\text { oli? }\end{array}$ & $\begin{array}{l}\text { Mis värvi oli kampsun/ } \\
\text { pluus? }\end{array}$ \\
\hline 10 & & Mis värvi seelik/püksid olid? & Mis värvi oli seelik/püksid? \\
\hline 11 & & Mis tal jalas oli? & Mis tal oli jalas? \\
\hline 12 & & Mis värvi need olid? & Mis värvi olid need? \\
\hline 13 & & Kui vana ta oli? & Kui vana oli ta? \\
\hline 14 & Mis ta tegi? & & \\
\hline 15 & Mis sul veel meeles on? & & \\
\hline
\end{tabular}

\section{Tulemused}

\subsection{Vaba meenutuse tulemused}

Kõigepealt lasti lastel juhtunud olukorda vabalt meenutada (Eile käis teil keegi rühmas. Mis sul selle kohta meeles on?). Varasemaid laste küsitlemise tulemusi arvestades eeldati, et vaba meenutuse käigus meenub lastele kõige rohkem 
informatsiooni. Kuid vaba meenutusega saadi informatsiooni ainult 13 lapselt (üks 4-aastane, kaksteist 6-aastast). Analüüsiti vaba meenutuse infoühikute hulka ning informatsiooni õigsust.

Vastuseid saadi stiimuli nime ja tegevuse kohta, muid asjaolusid lapsed ei maininud. Kokku saadi 24 infoühikut, millest 22 olid õiged (92\% vastustest). Nii nime kui ka tegevust mainis vabas meenutuses kaks 6-aastast last ja nende vastused olid õiged. Ainult stiimuli nime mainis vaba meenutuse käigus üks 6-aastane laps; tema vastus oli vale. Stiimuli tegevust mainis 10 last, neist üks oli 4-aastane ja ülejäänud 6-aastased. Kõik 6-aastased mäletasid stiimuli tegevust õigesti, üks 4-aastane vastas valesti.

\subsection{Sõnajärje ja küsitleja mõju laste vastustele}

Vaadeldes sõnajärje mõju laste vastustele, on tabelis 2 esmalt välja toodud laste antud vastuste keskmine infoühikute arv küsimuse kohta, standardhälve ja koguarv ning laste vastuste täpsus. Vastajate koguarv eri sõnajärjega küsimustele erineb, kuna mõne lapse käest küsiti ainult ühe sõnajärjega küsimusi $(n=41)$ ja teiste käest mõlema sõnajärjega küsimusi $(\mathrm{n}=59)$.

Levene testiga selgus, et andmed ei vasta normaaljaotusele, mistõttu kasutati erinevuste võrdlemisel mitteparameetrilist Kruskal-Wallise testi. Sõnajärje ja vanuse mõjus infoühikute hulgale statistiliselt olulisi erinevusi ei ilmnenud. Samuti ei mõjutanud sõnajärg laste antud vastuste täpsust. Samas ilmnesid vastuste täpsuses vanuselised erinevused: nimelt olid 6-aastaste laste vastused täpsemad $(\mathrm{M}=0,26 ; \mathrm{SD}=0,19)$ kui 4-aastaste omad $\left(\mathrm{M}=0,20 ; \mathrm{SD}=0,19 ; \chi^{2}(1)=3,89\right.$; $\mathrm{p}<, 05)$.

Järgnevalt on tabelis 3 välja toodud laste antud vastuste infoühikute ja täpsuse keskmised, standardhälbed ja vastuste koguarv, võttes arvesse eri küsitlejaid ja nende erinevaid küsitlusviise (läbivalt ainult ühe või teise sõnajärje kasutamine vs. juhuslikustatud küsitlemine, kus ühe lapse käest küsiti mõlema sõnajärjega küsimusi). Tabelist 3 on näha, et enam infoühikuid esitasid ning olid oma vastustes täpsemad lapsed, keda intervjueeris küsitleja 1 (tema küsis ainult ühe sõnajärjega küsimusi). Need lapsed esitasid oma vastustes keskmiselt 0,71 infoühikut ning nende vastuste täpsus oli keskmiselt 0,37 infoühikut. Küsitleja 2 intervjueeritud lapsed (küsimusi küsiti juhuslikustatud järjekorras) esitasid keskmiselt 0,51 infoühikut ning nende vastuste täpsus oli o,19 infoühikut.

Statistiliselt oluline erinevus ilmnes kahele küsitlejale antud infoühikute arvus $\left(\chi^{2}(1)=8,25 ; p<, 01\right)$. Ainult üht sõnajärge kasutanud küsitleja 1 küsimustele vastasid lapsed pikemalt võrreldes juhuslikustatud küsitlemisega (küsitleja 2). Statistiliselt oluline erinevus ilmnes ka küsitlejatele antud täpsetes infoühikutes $\left(X^{2}(1)=27,82 ; p<, 001\right)$. Lapsed vastasid täpsemalt, kui küsimused olid esitatud kogu intervjuus ainult ühe sõnajärjega (küsitleja 1). 
Tabel 2. Lapsele esitatud küsimuse sõnajärje mõju vastuse kvantiteedile ja kvaliteedile

\begin{tabular}{|c|c|c|c|c|c|}
\hline Vastus & Vanus & Sõnajärg & M & SD & $\mathbf{N}$ \\
\hline \multirow{9}{*}{ Sõnade arv } & \multirow{3}{*}{ 4-aastased } & Sõnajärg 1 & 0,52 & 0,44 & 32 \\
\hline & & Sõnajärg 2 & 0,57 & 0,46 & 32 \\
\hline & & Kokku & 0,55 & 0,46 & 64 \\
\hline & \multirow{3}{*}{ 6-aastased } & Sõnajärg 1 & 0,56 & 0,40 & 48 \\
\hline & & Sõnajärg 2 & 0,58 & 0,36 & 48 \\
\hline & & Kokku & 0,57 & 0,38 & 96 \\
\hline & \multirow{3}{*}{ Kokku } & Sõnajärg 1 & 0,54 & 0,42 & 80 \\
\hline & & Sõnajärg 2 & 0,58 & 0,40 & 80 \\
\hline & & Kokku & 0,56 & 0,40 & 160 \\
\hline \multirow{9}{*}{ Täpsus } & \multirow{3}{*}{ 4-aastased } & Sõnajärg 1 & 0,20 & 0,20 & 32 \\
\hline & & Sõnajärg 2 & 0,20 & 0,18 & 32 \\
\hline & & Kokku & 0,20 & 0,19 & 64 \\
\hline & \multirow{3}{*}{ 6-aastased } & Sõnajärg 1 & 0,20 & 0,19 & 48 \\
\hline & & Sõnajärg 2 & 0,31 & 0,18 & 48 \\
\hline & & Kokku & 0,26 & 0,19 & 96 \\
\hline & \multirow{3}{*}{ Kokku } & Sõnajärg 1 & 0,20 & 0,19 & 80 \\
\hline & & Sõnajärg 2 & 0,27 & 0,19 & 80 \\
\hline & & Kokku & 0,23 & 0,19 & 160 \\
\hline
\end{tabular}

Lühendid: $\mathrm{M}=$ keskmine; $\mathrm{SD}=$ standardhälve; $\mathrm{N}=$ katseisikute arv.

Tabel 3. Küsitleja mõju laste antud vastuste kvantiteedile ja kvaliteedile

\begin{tabular}{|l|l|l|c|c|c|c|c|}
\hline \multirow{2}{*}{ Vastus } & \multirow{2}{*}{ Küsitleja } & \multicolumn{2}{|c|}{ Kokku } & \multicolumn{2}{c|}{ 4-aastased } & \multicolumn{2}{c|}{ 6-aastased } \\
\cline { 3 - 8 } & & M (SD) & $\mathbf{N}$ & $\mathbf{M}($ SD) & $\mathbf{N}$ & M (SD) & N \\
\hline \multirow{4}{*}{ Sõnade arv } & K1 & $0,71(0,36)$ & 42 & $0,63(0,33)$ & 16 & $0,75(0,38)$ & 26 \\
\cline { 2 - 8 } & K2 & $0,51(0,41)$ & 118 & $0,52(0,48)$ & 48 & $0,50(0,36)$ & 70 \\
\cline { 2 - 8 } & Kokku & $0,56(0,41)$ & 160 & $0,55(0,45)$ & 64 & $0,57(0,38)$ & 95 \\
\hline \multirow{3}{*}{$\begin{array}{l}\text { Vastuse } \\
\text { täpsus }\end{array}$} & K1 & $0,37(0,15)$ & 41 & $0,34(0,17)$ & 16 & $0,38(0,14)$ & 26 \\
\cline { 2 - 8 } & K2 & $0,19(0,18)$ & 118 & $0,15(0,18)$ & 48 & $0,21(0,18)$ & 70 \\
\cline { 2 - 8 } & Kokku & $0,23(0.19)$ & 159 & $0,20(0,19)$ & 64 & $0,26(0,19)$ & 95 \\
\hline
\end{tabular}

Lühendid: $\mathrm{M}=$ keskmine; $\mathrm{SD}=$ standardhälve; $\mathrm{N}$ = katseisikute arv; $\mathrm{K} 1$ = küsitleja 1; K2 = küsitleja 2.

\subsection{Sõnajärje mõju üksikute küsimuste kaupa}

Katse tulemusi küsimuste kaupa analüüsides on võimalik vaadelda, kas mõnele küsimusele vastamisel oli sõnajärjel olulisem roll kui teiste küsimuste puhul. Iga küsimust vaadeldakse kahest aspektist: kas küsimusele vastati õige või vale (nt jättis küsimusele vastamata või vastas vale infoga) kategooriaga ning kas küsimuse vastused olid õiged või mitte.

Analüüsides üksikküsimusi (vt tabel 4), ealisi ning sõnajärjest tulenevaid erinevusi infoühikute hulgas ei ilmnenud. Samuti ei ilmnenud sõnajärje mõju infoühikute täpsusele. Küll aga ilmnesid ealised erinevused laste vastustes infoühikute 
täpsusele Kruskal-Wallise testi kasutades, nimelt, 6-aastased lapsed meenutasid täpsemalt kui 4-aastased lapsed nähtud isiku juukseid $\left(\chi^{2}(1)=5,86 ; p<, 05\right)$ ja riideid $\left(\chi^{2}(1)=5,84 ; p<, 05\right)$.

Tabel 4. Esitatud infoühikute ja õigete vastuste keskmised küsimuseti

\begin{tabular}{|c|c|c|c|c|c|c|c|c|c|c|c|c|c|}
\hline \multirow{3}{*}{ Tunnus } & \multirow{3}{*}{ Vastus } & \multicolumn{6}{|c|}{ 4-aastased } & \multicolumn{6}{|c|}{ 6-aastased } \\
\hline & & \multicolumn{3}{|c|}{ Sõnajärg 1} & \multicolumn{3}{|c|}{ Sõnajärg 2} & \multicolumn{3}{|c|}{ Sõnajärg 1} & \multicolumn{3}{|c|}{ Sõnajärg 2} \\
\hline & & M & SD & $\mathbf{n}$ & M & SD & $\mathbf{n}$ & M & SD & $\mathbf{n}$ & $\mathbf{M}$ & SD & $\mathbf{n}$ \\
\hline \multirow{2}{*}{ sugu } & 1 & 0,77 & 0,48 & 39 & - & - & - & 0,93 & 0,25 & 61 & - & - & - \\
\hline & $T$ & 0,54 & 0,51 & 39 & - & - & - & 0,92 & 0,28 & 61 & - & - & - \\
\hline \multirow{2}{*}{ nimi } & 1 & 0,05 & 0,23 & 19 & 0,20 & 0,41 & 20 & 0,10 & 0,31 & 29 & 0,13 & 0,34 & 32 \\
\hline & $T$ & 0,00 & 0,00 & 19 & 0,10 & 0,31 & 20 & 0,10 & 0,31 & 29 & 0,06 & 0,25 & 32 \\
\hline \multirow{2}{*}{ välimus } & 1 & 1,05 & 1,58 & 19 & 1,05 & 1,54 & 20 & 0,86 & 1,13 & 29 & 0,75 & 1,14 & 32 \\
\hline & $T$ & 0,32 & 0,48 & 19 & 0,25 & 0,44 & 20 & 0,28 & 0,45 & 29 & 0,31 & 0,47 & 32 \\
\hline \multirow{2}{*}{ kehakuju } & 1 & 0,63 & 0,50 & 19 & 1,00 & 1,49 & 20 & 1,21 & 1,08 & 29 & 0,97 & 0,59 & 32 \\
\hline & $T$ & 0,53 & 0,51 & 19 & 0,50 & 0,51 & 20 & 0,69 & 0,47 & 29 & 0,66 & 0,48 & 32 \\
\hline \multirow{2}{*}{ nägu } & 1 & 0,62 & 0,74 & 21 & 0,50 & 0,51 & 18 & 0,63 & 0,98 & 32 & 0,79 & 0,98 & 29 \\
\hline & $T$ & 0,38 & 0,50 & 21 & 0,22 & 0,43 & 18 & 0,31 & 0,47 & 32 & 0,34 & 0,48 & 29 \\
\hline \multirow{2}{*}{ juuksed } & 1 & 1,16 & 1,21 & 19 & 1,05 & 0,76 & 20 & 1,48 & 1,30 & 29 & 1,53 & 1,08 & 32 \\
\hline & $\mathrm{T}$ & 0,47 & 0,51 & 19 & 0,45 & 0,51 & 20 & 0,66 & 0,48 & 29 & 0,75 & 0,44 & 32 \\
\hline \multirow{2}{*}{$\begin{array}{l}\text { juukse- } \\
\text { värv }\end{array}$} & 1 & 0,26 & 0,45 & 19 & 0,35 & 0,59 & 20 & 0,34 & 0,55 & 29 & 0,31 & 0,47 & 32 \\
\hline & $\mathrm{T}$ & 0,26 & 0,45 & 19 & 0,20 & 0,41 & 20 & 0,38 & 0,49 & 29 & 0,38 & 0,49 & 32 \\
\hline \multirow{2}{*}{ seljas } & I & 0,86 & 1,28 & 21 & 0,83 & 0,92 & 18 & 1,06 & 0,95 & 32 & 1,24 & 1,55 & 29 \\
\hline & $\mathrm{T}$ & 0,14 & 0,36 & 21 & 0,28 & 0,46 & 18 & 0,47 & 0,51 & 32 & 0,41 & 0,50 & 29 \\
\hline \multirow{2}{*}{ kampsun } & 1 & 0,74 & 0,81 & 19 & 0,55 & 0,76 & 20 & 0,38 & 0,56 & 29 & 0,38 & 0,49 & 32 \\
\hline & $\mathrm{T}$ & 0,32 & 0,48 & 19 & 0,10 & 0,31 & 20 & 0,31 & 0,47 & 29 & 0,25 & 0,44 & 32 \\
\hline \multirow{2}{*}{ seelik } & 1 & 0,48 & 0,75 & 21 & 0,28 & 0,46 & 18 & 0,44 & 0,62 & 32 & 0,52 & 0,57 & 29 \\
\hline & $\mathrm{T}$ & 0,14 & 0,36 & 21 & 0,11 & 0,32 & 18 & 0,22 & 0,42 & 32 & 0,24 & 0,44 & 29 \\
\hline \multirow{2}{*}{ jalas } & 1 & 0,67 & 0,58 & 21 & 0,61 & 0,61 & 18 & 0,81 & 0,64 & 32 & 0,79 & 0,98 & 29 \\
\hline & $\mathrm{T}$ & 0,38 & 0,50 & 21 & 0,22 & 0,43 & 18 & 0,25 & 0,44 & 32 & 0,10 & 0,31 & 29 \\
\hline \multirow{2}{*}{$\begin{array}{l}\text { jalatsi } \\
\text { värv }\end{array}$} & 1 & 0,26 & 0,45 & 19 & 0,50 & 0,61 & 20 & 0,34 & 0,48 & 29 & 0,28 & 0,46 & 32 \\
\hline & $\mathrm{T}$ & 0,05 & 0,23 & 19 & 0,10 & 0,31 & 20 & 0,07 & 0,26 & 29 & 0,09 & 0,30 & 32 \\
\hline \multirow{2}{*}{ vanus } & 1 & 0,32 & 0,48 & 19 & 0,30 & 0,47 & 20 & 0,34 & 0,48 & 29 & 0,44 & 0,72 & 32 \\
\hline & $\mathrm{T}$ & 0,05 & 0,23 & 19 & 0,05 & 0,22 & 20 & 0,10 & 0,31 & 29 & 0,22 & 0,42 & 32 \\
\hline \multirow{2}{*}{ tegevus } & I & 1,08 & 0,87 & 39 & - & - & - & 1,66 & 1,09 & 61 & - & - & - \\
\hline & $\mathrm{T}$ & 0,51 & 0,51 & 39 & - & - & - & 0,75 & 0,43 & 61 & - & - & - \\
\hline \multirow{2}{*}{ muu } & 1 & 0,49 & 1,32 & 39 & - & - & - & 0,36 & 0,93 & 61 & - & - & - \\
\hline & $\mathrm{T}$ & 0,10 & 0,31 & 39 & - & - & - & 0,18 & 0,39 & 61 & - & - & - \\
\hline
\end{tabular}

Lühendid: I = infoühik; $T$ = täpsus; $M$ = keskmine; $S D=$ standardhälve, $\mathrm{n}=$ katseisikute arv.

Stiimuli nime küsimisel (Mis oli ta nimi? Mis ta nimi oli?) vastas õige kategooriaga (nimega) 15\% 4-aastastest ja 11\% 6-aastastest lastest. 4-aastastest lastest enamik ütles, et nad nähtud isiku nime ei tea või ei mäleta, kuid pakuti väljamõeldud nimesid, nt Martsits. 4-aastased lapsed andsid 10\% rohkem õigeid vastuseid, kui 
verb oli küsimuse keskel; 6-aastased lapsed andsid 4\% rohkem õigeid vastuseid, kui verb oli küsimuse lõpus.

Kõige enam varieerusid välimuse küsimuse vastused (Milline nägi ta välja? Milline ta välja nägi?), millele vastas õige kategooriaga 15\% 4-aastatest ja 5\% 6-aastastest lastest. Kuna täpsemate kirjelduste saamiseks tuleb meenutamist võimalikult vähe suunata, alustati välimusest rääkimist laiematest küsimustest ja suunduti siis konkreetsemate juurde (küsimused riietuse, juuste, jalatsite kohta). Kui laps sellele üldisele küsimusele vastates juba järgmiste küsimuste vastuseid mainis, siis neid hiljem enam uuesti ei küsitud. Õigeks loeti välimuse küsimuse vastused, kus laps mainis rohkem kui üht välimuse aspekti. Kui laps mainis vaid üht aspekti, märgiti see vastava kategooriaga (nt juuksevärv, soeng, riided, hindav väljend vms).

Mainitud eri kategooriate hulk annab aimu, kui lai on laste jaoks mõiste välimus. 11 last (üks 4-aastane ja kümme 6-aastast) andsid vastuseks stiimuli juuksevärvi. Seitse last (kolm 4-aastast ja neli 6-aastast) mainis soengut (juuste pikkus, lokid, pats vms) 12 last (viis 4-aastast ja seitse 6-aastast) rääkis stiimuli riietusest. Kolm last (kaks 4-aastast ja üks 6-aastane) andis vastuseks hinnangu (nt ta oli ilus). Üks 6-aastane laps vastas küsimusele võrdlusega (ta nägi välja nagu koosolekutädi), üks 4-aastane laps kirjeldas stiimuli tegevust ning samuti üks 4-aastane laps rääkis stiimuli vanusest. 4-aastased andsid $28 \%$ rohkem õigeid vastuseid, kui verb asus küsilause keskel; 6-aastased andsid 15\% rohkem õigeid vastuseid aga verbilõpulise sõnajärjega küsimusele.

Kehakuju kohta (Milline oli ta kehakuju? Milline ta kehakuju oli?) andis õigesse kategooriasse kuuluva vastuse 62\% 4-aastastest ja 79\% 6-aastastest lastest. Sellele küsimusele vastas väike hulk 6-aastasi lapsi mõne muu kategooriaga. Kaks last joonistas õhku mingi ebamäärase kujundi või joone, üks laps rääkis stiimuli pikkusest, üks vastas hindava väljendiga (ilus) ja üks kirjeldas stiimuli kehakuju värviga. Kui küsiti küsimusi, milles verb oli lause keskel, saadi 4-aastastelt $6 \%$ ja 6-aastastelt 5\% rohkem õigeid vastuseid.

Näo kirjeldamise küsimusele (Milline oli ta nägu? Milline ta nägu oli?) vastas õige kategooriaga 33\% 4-aastastest ja 34\% 6-aastastest lastest. Ka selle küsimuse vastustes toodi välja erinevaid kategooriaid. Viis 6-aastast last vastas hindava väljendiga (nt ilus, kõige ilusam), kaks 4-aastast ja üks 6-aastane andsid vastuseks värvi (roheline), kaks 6-aastast vastasid võrdlusega (nt võrdlesid stiimulit küsitlejaga), samuti kaks last, üks 4-aastane ja üks 6-aastane, joonistasid vastuseks õhku ebamäärase kujundi. Üks 6-aastane laps kirjeldas stiimuli soengut, üks 4-aastane tõi välja, et stiimul kandis prille, samuti oli üks 4-aastane, kes vastas küsimusele värviga ja üks tõi välja vanuse. 4-aastased andsid $42 \%$ rohkem õigeid vastuseid küsimusele, kus küsisõna oli lause keskel; 6-aastased andsid 9\% rohkem õigeid vastuseid küsimusele, kus küsisõna oli lause lõpus.

Sarnaselt välimuse kirjeldamise küsimusega loeti ka juuste kirjeldamisel (Millised olid tajuuksed? Millised tajuuksed olid?) õigesse kategooriasse vastused, mis sisaldasid rohkem kui üht tunnust (nt pikkus, soeng, värv). Kui laps vastas ainult ühe tunnusega, märgiti see vastavasse kategooriasse. Küsimusele vastas õige kategooriaga 33\% 4-aastastest ja 39\% 6-aastastest lastest. Täpselt sama proportsioon lapsi vastas küsimusele ainult juuksevärvi kohta. Kuus last, kolm 4- ja kolm 6-aastast vastas ainult soengu kirjeldusega ning üks 6-aastane laps kasutas vastamiseks võrdlust - võrdles stiimuli juukseid küsitleja omadega. Suur hulk lapsi 
alustas juuste kirjeldamist juuksevärvist ja rohkem kui kolmandik neist ei lisanudki kirjeldusele midagi juurde. 4-aastased andsid esimese sõnajärjega (verb lause keskel) küsimusele 4\% rohkem õigeid vastuseid. 6-aastased andsid $12 \%$ rohkem õigeid vastuseid aga teise sõnajärjega küsimusele. Kuna juuksevärvi vastus oli eelnevalt väga selgelt kätte saadud, jäi see küsimus (Mis oli ta juuksevärv? Mis ta juuksevärv oli?) 22 lapselt küsimata. Ülejäänud 78 lapsest vastas õige kategooriaga küsimusele 30\% lastest (28\% 4-aastastest ja 31\% 6-aastastest).

Riietuse küsimuses (Mis oli tal seljas? Mis tal seljas oli?) loeti kategooria õigeks, kui laps vastas vähemalt ühe konkreetse riideesemega, nt kleit, särk, kampsun, püksid (49\% 4-aastastest ja 52\% 6-aastastest). Kaks 6-aastast vastas üldsõnaliselt, et stiimulil olid seljas riided. Üks 6-aastane laps vastas ainult värviga (mustad). 4-aastased andsid 50\% rohkem õigeid vastuseid, kui verb oli küsilause lõpus. 6-aastaste hulgas andis 13\% rohkem õigeid vastuseid aga esimese sõnajärjega (verb lause keskel) küsimus.

Järgmised kaks küsimust puudutasid riietuse värvust (Mis värvi oli ta kampsun? Mis värvi ta kampsun oli? Mis värvi oli seelik/püksid? Mis värvi seelik/ püksid olid?). Kampsuni värvi küsimusele vastas õige kategooriaga 40\% lastest (49\% 4-aastastest ja 34\% 6-aastastest). 4-aastased andsid 69\% ja 6-aastased 20\% rohkem õigeid vastuseid juhtudel, milles verb on küsilause keskel. Seeliku või pükste küsimusele andis õige kategooriaga vastuse 39\% lastest (31\% 4-aastastest ja 44\% 6-aastastest). 4-aastaste hulgas andis rohkem õigeid vastuseid küsimus, milles verb oli küsilause keskel (22\% rohkem õigeid vastuseid); 6-aastased andsid $8 \%$ rohkem õigeid vastuseid verbilõpulise küsimuse korral.

Jalatsite küsimusele (Mis oli tal jalas? Mis tal jalas oli?) vastas õige kategooriaga 56\% 4-aastastest ja 57\% 6-aastastest lastest. Üks 4-aastane laps vastas ainult värviga. Paremaid tulemusi andis verbilõpulise sõnajärjega küsimus, millele saadi 4-aastastelt $42 \%$ ja 6 -aastastelt $60 \%$ rohkem õigeid vastuseid. Jalatsite värvi küsimusele (Mis värvi olid need? Mis värvi need olid?) vastas õige kategooriaga 34\% lastest (36\% 4-aastastest ja 33\% 6-aastastest). Nii 4- kui ka 6-aastased andsid rohkem õigeid vastuseid verbilõpulise sõnajärjega küsimuse korral (vastavalt 50\% ja $22 \%$ rohkem).

Vanuse küsimusele (Kui vana oli ta? Kui vana ta oli?) vastas õige kategooriaga 39\% 4-aastastest ja 34\% 6-aastastest lastest. Õige vanuse määramisega lapsed siiski veel toime ei tulnud - nähtud isikute vanuseks pakuti nii üht kuud, paari aastat kui ka 75 ja 100 aastat. Vastati ka hindava väljendiga, nt väga vana. 4-aastastele polnud küsimuse sõnajärg oluline - õigeid vastuseid saadi võrdsel hulgal; 6-aastased andsid verbilõpulise sõnajärjega küsimusele $22 \%$ rohkem õigeid vastuseid.

Kolme küsimuse sõnajärge ei varieeritud. Nähtud isiku sugu mäletati üpris hästi. Õige kategooriaga (mees/naine) vastas 93\% 6-aastastest ja 74\% 4-aastastest lastest. Järgmise kahe küsimuse vastustes (Mis ta tegi? Mis sul veel meeles on?) loeti õigeks kategooriaks igasugune mainitud tegevus. Tegevuse küsimusele vastas õige kategooriaga 79 last, 21 toimunut ei mäletanud. Vastuses viimasele küsimusele ei lisanud 82 last oma jutule enam midagi. Lapsed kippusid juba öeldut kordama. Enim räägiti stiimuli tegevusest. Neli 6-aastast last mäletasid väga hästi stiimuli räägitut (nt stiimul õpib ülikoolis keemiat või on pärit Saaremaalt). Üks 6-aastane laps tõi vastuses välja ajakategooria, mainides, et kõik seni meenutatu oli toimunud eelmisel päeval. 


\section{Kokkuvõte ja arutelu}

Uurimuse eesmärgiks oli leida lastele esitatavate erineva sõnajärjega küsimuste mõju vastuste kvaliteedile ja kvantiteedile ning samuti uurida vanuseliste erinevuste ilmnemist küsimustele vastamisel.

Tulemustest selgus, et sõnajärg (verb küsimuse keskel või lõpus) ei omanud statistiliselt olulist mõju ei infoühikute hulgale ega täpsusele. 4-aastased lapsed vastasid esimese sõnajärjega küsimustele (verb küsimuse lõpus) väiksema infohulgaga kui teise sõnajärjega küsimustele (verb küsimuse keskel), erinevus oli 10\%; 6-aastaste laste tulemus oli sarnane (erinevus 4\%). Vastuse täpsuse osas andsid 4-aastased lapsed sama täpseid vastuseid sõnajärje varieerimisel, samas kui 6-aastased lapsed vastasid teise sõnajärjega küsimustele 55\% täpsemalt kui esimese sõnajärjega küsimustele. Selliste kohati vastukäivate tulemuste üheks võimalikuks põhjuseks võib olla käesoleva uuringu andmekogumismeetod. Samas võib selliseid tulemusi mõjutada ka asjaolu, et eelkoolieas on individuaalsete erinevuste roll keelereeglite omandamisel suurem võrreldes koolieaga (Shore 1995). Sellest tulenevalt tuleks edaspidi kindlasti uurida eesti laste sõnajärje omandamist.

Lähemalt vaadeldi ka seda, kas lapsed vastasid täpsemalt siis, kui neilt küsiti kogu küsitluse vältel ainult ühe sõnajärjega küsimusi (kas verb alati küsimuse keskel või alati küsimuse lõpus) või varieeriti sõnajärge (kord verb küsimuse keskel, kord küsimuse lõpus). Selgus, et vastuse sõnade arvus statistiliselt olulisi erinevusi ei avaldunud, kuigi läbivalt ainult ühte või teist sõnajärge kasutades olid laste vastused keskmiselt 39\% pikemad. Statistiliselt olulised erinevused avaldusid info täpsuses, kus samuti ainult ühte või teist sõnajärge kasutades olid laste vastused keskmiselt 95\% täpsemad. Üksikküsimuste kaupa laste vastuste kvantiteet küll erines, aga need erinevused polnud statistiliselt olulised.

Statistiliselt olulised vanuselised erinevused ilmnesid info kvaliteedis, aga mitte kvantiteedis. 6-aastased lapsed olid küsimustele vastates täpsemad kui 4-aastased lapsed (erinevus 30\%), mis seostub varasemate uuringute tulemustega, kus vanemate laste meenutamisvõime on parem kui noorematel lastel (Kask, Bull 2009). Sama kinnitab ka antud uurimuse järeldus, et 6-aastased lapsed meenutasid täpsemalt kui 4-aastased lapsed nähtud isiku juukseid ja riideid. Samas ei mõjutanud vastustes täpsust erineva sõnajärje kasutamine.

Vabas meenutuses andsid rohkem infot 6-aastased lapsed; 4-aastased vastasid pigem, et nad ei mäleta midagi. Varasemalt on teada, et ehkki vaba meenutuse käigus annavad informatsiooni vähesed (vt ka Kask, Bull 2009), on niimoodi saadud informatsioon täpsem, sest lapsed räägivad sellest, mis neil tõesti meeles on (Lamb jt 2008). Sellest lähtuvalt on oluline lastel lasta sündmuse asjaolusid vaba meenutust kasutades meelde tuletada.

Uuringu nõrkadeks külgedeks võib lugeda mitmeid asjaolusid. Esiteks, kasutati erinevaid andmekogumismeetodeid - lastega läbi viidud intervjuud mõnel juhul audiosalvestati, mõnel juhul kirjutati vastused paberile. Teiseks, kasutati eri stiimulisikuid, mistõttu stiimulisikute erinevused võisid mõjutada katseisikute vastuseid. Kolmandaks, kuna üks küsitleja küsitles lapsi, kasutades ainult üht või teist sõnajärge, aga teine küsitleja läbisegi erineva sõnajärjega küsimusi, siis ei saa olla kindel, kas sellise erineva küsitlemise efekt tuleneb küsitlejast endast või 
küsitlemise viisist. Edasistes uurimustes peaks seda asjaolu arvesse võtma ning ühe sõnajärjega küsimusi peaks küsima vähemalt kaks küsitlejat.

Kokkuvõtlikult võib öelda, et sõnajärje mõju laste vastuste kvantiteedile ja kvaliteedile uuringust ei ilmnenud. Samas leiti, et ainult ühe sõnajärjega küsimusi kasutades on laste meenutused täpsemad võrreldes sõnajärje vaheldamisega. See annab alust arvata, et lastele on arenguliselt kergem vastata ühe sõnajärjega küsimustele, olenemata sellest, kas tegusõna on küsimuse alguses või lõpus. Seega võiks soovitada, et kui lastelt küsimusi küsida ning oluline on saada täpset infot, siis ei tasuks erineva sõnajärjega küsimusi läbisegi küsida, vaid küsida läbivalt kas üht või teist sõnajärge kasutades.

\section{Viidatud kirjandus}

Ceci, Stephen J.; Crossman, Angela M.; Gilstrap, Livia L.; Scullin, Matthew H. 1998. Social and cognitive factors in children's testimony. - Charles P. Thompson, Douglas J. Herrmann, J. Don Read, Darryl Bruce, David G. Payne, Michael P. Toglia (Eds.), Eyewitness Memory: Theoretical and Applied Perspectives. New Jersey: Lawrence Erlbaum Associates, 15-30.

Ceci, Stephen J.; Bruck, Maggie 1995. Jeopardy in the Courtroom. Washington, DC: American Psychological Association.

Davies, Graham M.; Stevenson-Robb, Y.; Flin, Rhona 1988. Tales out of school: Children's memory for an unexpected event. - Michael M. Gruneberg, Peter E. Morris (Eds.), Practical Aspects of Memory: Current Research and Issues, Vol. 1: Memory in Everyday Life. Oxford: John Wiley \& Sons, 122-127.

Dekle, Dawn J.; Beal, Carole R.; Elliott, Rogers; Huneycutt, Dominique 1996. Children as witnesses: A comparison of lineup versus showup identification methods. - Applied Cognitive Psychology, 10, 1-12.

EKG 1993 = Erelt, Mati; Kasik, Reet; Metslang, Helle; Rajandi, Henno; Ross, Kristiina; Saari, Henn; Tael, Kaja; Vare, Silvi 1993. Eesti keele grammatika. II. Süntaks. Trükki toimetanud Mati Erelt (peatoimetajana), Tiiu Erelt, Henn Saari, Ülle Viks. Tallinn: Eesti Teaduste Akadeemia, Keele ja Kirjanduse Instituut.

EKK = Erelt, Mati; Erelt, Tiiu; Ross, Kristiina 2007. Eesti keele käsiraamat. 3., täiendatud trükk. Tallinn: Eesti Keele Sihtasutus.

Ellis, Hadyn D. 1990. Developmental trends in face recognition. - The Psychologist, 3, 114-119.

Hutcheson, Graeme D.; Baxter, James S.; Telfer, Karen; Warden, David 1995. Child witness statement quality: Question type and errors of omission. - Law and Human Behavior, 19 (6), 631-648. http://dx.doi.org/10.1007/BFo1499378

Kask, Kristjan 2007. Arengupõhiselt sobivad meetodid laste küsitlemiseks. - Juridica, 4, 229-238.

Kask, Kristjan 2012. Dynamics in using different question types in Estonian police interviews of children. - Applied Cognitive Psychology, 26 (2), 324-329. http://dx.doi. org/10.1002/acp.1831

Kask, Kristjan; Bull, Ray; Heinla, Indrek; Davies, Graham 2007. The effect of a standard to improve person descriptions by children. - Journal of Police and Criminological Psychology, 22 (2), 77-83. http://dx.doi.org/10.1007/s11896-007-9008-1

Kask, Kristjan; Bull, Ray 2009. From person descriptions to interviewing methods: What can be done to improve child witnesses' testimonies? - Trames, 13 (2), 9-108. http:// dx.doi.org/10.3176/tr.2009.2.01

King, M. A.; Yuille, John C. 1986. An investigation of the witness abilities of children. Publitseerimata käsikiri. University of British Columbia. 
Lamb, Michael E.; Sternberg, Kathleen J.; Esplin, Phillip W. 2000. Effects of age and delay on the amount of information provided by alleged sex abuse victims in investigative interviews. - Child Development, 71 (6), 1586-1596. http://dx.doi. org/10.1111/1467-8624.00250

Lamb, Michael E.; Hershkowitz, Irit; Orbach, Yael; Esplin, Phillip W. 2008. Tell Me What Happened. Chichester, UK-Hoboken, NJ: Wiley. http://dx.doi.org/10.1002 $\angle 9780470773291$

Lindström, Liina 2002. Veel kord subjekti ja predikaadi vastastikusest asendist laiendi järel. - Emakeele Seltsi aastaraamat, 47 (2001), 87-106.

Lindström, Liina 2005. Finiitverbi asend lauses. Sõnajärg ja seda mõjutavad tegurid suulises eesti keeles. Dissertationes philologiae estonicae Universitatis Tartuensis 16. Tartu: Tartu Ülikooli Kirjastus.

Lindström, Liina, ilmumas. Lause sõnajärg. Eesti keele süntaks (käsikiri Tartu Ülikoolis).

Meissner, Christian A.; Sporer, Siegfried L.; Schooler, Jonathan F. 2006. Person descriptions as eyewitness evidence. - R. C. Lindsay, David F. Ross, J. Don Read, Micheal P. Toglia (Eds.), Handbook of Eyewitness Psychology: Memory for People. Mahwah, NJ: Lawrence Erlbaum, 3-34.

Orbach, Yael; Hershkowitz, Irit; Lamb, Michael E.; Sternberg, Kathleen J.; Esplin, Phillip W.; Horowitz, Dvora 2000. Assessing the value of structured protocols for forensic interviews of alleged abuse victims. - Child Abuse and Neglect, 24 (6), 733-752. http:// dx.doi.org/10.1016/S0145-2134(00)00137-X

Paju, Liina 2014. Ammendavuse omandamisest nelja-aastaste eesti laste katsematerjali näitel. Publitseerimata bakalaureusetöö. Tallinn: Tallinna Ülikool, eesti keele ja kultuuri instituut.

Poole, Debra A.; White, Lawrence T. 1991. Effects of question repetition on the eyewitness testimony of children and adults. - Developmental Psychology, 27 (6), 975-986. http://dx.doi.org/10.1037/0012-1649.27.6.975

Poole, Debra A.; Dickinson, Jason J. 2013. Investigative interviews of children. - Robin E. Holliday, Tammy A. Marche (Eds.), Child Forensic Psychology. Hampshire, UK: Palgrave Macmillan, 157-179.

Rammo, Ruta 2006. Alaealise ülekuulamine kriminaalmenetluse kohtueelses staadiumis. Juridica, 5, 317-328.

Shore, Cecilia M. 1995. Individual Differences in Language Development. Thousand Oaks, CA: Sage. http://dx.doi.org/10.4135/9781483327150

Sporer, Siegfried L. 1996. Psychological aspects of person descriptions. - Siegfried L. Sporer, Roy S. Malpass, Guenter Koehnken (Eds.), Psychological Issues in Eyewitness Identification. New Jersey: Lawrence Erlbaum Associates, 53-86.

Sternberg, Kathleen J.; Lamb, Michael E.; Orbach, Yael; Esplin, Phillip W.; Mitchell, Susanne 2001. Use of a structured investigative protocol enhances young children's responses to free-recall prompts in the course of forensic interviews. - Journal of Applied Psychology, 86 (5), 997-1005. http://psycnet.apa.org/doi/10.1037/0021-9010.86.5.997

Tael, Kaja 1988. Sõnajärjemallid eesti keeles (võrrelduna soome keelega). Preprint KKI-56. Tallinn: Eesti NSV Teaduste Akadeemia Keele ja Kirjanduse Instituut.

Tõugu, Pirko; Tulviste, Tiia; Schröder, Lisa; Keller, Heidi; De Geer, Boel 2011. Socialization of past event talk: Cultural differences in maternal elaborative reminiscing. - Cognitive Development, 26 (2), 142-154. http://dx.doi.org/10.1016/j.cogdev.2010.12.004 


\title{
THE EFFECT OF WORD ORDER IN QUESTIONS TO THE RECALL ACCURACY OF A PERSON OF 4- AND 6-YEARS-OLD ESTONIAN CHILDREN
}

\author{
Kristjan Kask, Reili Argus, Kristel Veerus, Kreet Kokla \\ Tallinn University
}

It is important to interview a child witness or victim in the criminal justice system in such a way that the information retrieved from a child would be accurate. The aim of the study was to examine the effect of the word order to the quality and quantity of the information. A hundred children (four- and six-year-olds) participated in an experiment where they saw an unfamiliar person and in the next day answered questions about the person. In asking questions different word order was used, i.e. whether the verb was in the middle or in the end of the sentence. For one group of children the questions were asked using only one or the other type of word order, for another group of the children the questions involved both type of word order. The results revealed that the word order itself did not have an effect to the quality nor quantity of the information. Six-year-olds were more accurate than four-year-olds in answering the questions. However, in comparison of whether only one type of word order (verb only in the middle or verb at the end of the questions) or random type of word order (in some questions verb in the middle and in some questions verb at the end) was used, statistically significant differences emerged in both total length and in accuracy of the answer favouring the case where only one type of word order was used. It can be suggested that in interviewing children only one type of word order (verb only in the middle or verb at the end of the questions) should be used.

Keywords: interviewing children, word order in questions, child language

Kristjan Kask (Tallinna Ülikooli loodus- ja terviseteaduste instituut) on erialalt psühholoog, doktorikraad õiguspsühholoogias Leicesteri Ülikoolist Suurbritannias. On uurinud täiskasvanud ja lapstunnistajate ütlusi.

Narva mnt 25, 10120 Tallinn, Estonia

kristjan.kask@tlu.ee

Reili Argus (Tallinna Ülikooli humanitaarteaduste instituut) on lingvist, kes on peamiselt tegelenud esimese keele omandamisega.

Narva mnt 25, 10120 Tallinn, Estonia

reili.argus@tlu.ee

Kristel Veerus (Tallinna Ülikooli humanitaarteaduste instituut) omandas 2015. aastal Tallinna Ülikoolis bakalaureusekraadi eesti filoloogias ning jätkab magistriõpinguid keeleteaduse ja keeletoimetamise erialal.

Narva mnt 25, 10120 Tallinn, Estonia

kristel.veerus@tlu.ee

Kreet Kokla (Tallinna Ülikooli loodus- ja terviseteaduste instituut) omandas 2015. aastal

Tallinna Ülikoolis bakalaureusekraadi psühholoogias.

Narva mnt 25, 10120 Tallinn, Estonia

kreet.kokla@tlu.ee 